\title{
Development and validation of a GC-FID method to quantify thymoquinone in black cumin seed oils
}

\author{
İlker DEMİRBOLAT 1, 2 * (D) , Murat KARTAL 1 (D) , Ünal KARIK ${ }^{3}$ (iD) \\ 1 Bezmialem Vakıf University, Center of Education, Practice and Research in Phytotherapy, 34093 Fatih, Istanbul, \\ Turkey. \\ 2 Department of Pharmaceutical Chemistry, Faculty of Pharmacy, Marmara University, 34668 Haydarpaşa, İstanbul, \\ Turkey. \\ 3 Department of Medicinal and Aromatic Plants, Aegean Agricultural Research Institute, 35660 Menemen, İzmir, \\ Turkey. \\ * Corresponding Author. E-mail: idemirbolat@bezmialem.edu.tr (İ.D.); Tel. +90 216523 22 88-1881.
}

Received: 05 October 2018 / Revised: 09 December 2018 / Accepted: 10 December 2018

ABSTRACT: Black cumin (Nigella sativa L.) is a very popular medicinal plant around the world. Pharmacological effects have been widely studied over the years. It has an economic importance and being cultivated in many parts of Turkey and neighbour countries. Thymoquinone (TQ) is a volatile compound found in black cumin seeds and a major compound of its essential and fixed oils which has been reported as anticancer, antidiabetic, spasmolytic, immunomodulator, bronchodilator, antimicrobial, analgesic, anti-inflammatory, antioxidant etc. The quality of black cumin seed oil depends on extraction technics (expression, super critic $\mathrm{CO}_{2}$ extraction etc.), quality of seeds, storage time and thymoquinone content. In this study we developed and validated a rapid quantification GC-FID method to determine the thymoquinone levels in seed oils which uses diethyl phthalate (DEP) as an internal standard.

KEYWORDS: Thymoquinone; gas chromatography; black cumin; Nigella sativa.

\section{INTRODUCTION}

Nigella sativa L. (NS) known as black cumin, is a member of Ranunculaceae family and an annual herbaceous plant native to Mediterranean region. Its seeds are used for edible and medicinal purposes all over the world [1]. Seeds taste bitter, contains fixed-essential oils and are high in proteins, flavonoids, glycosides, alkaloids, saponins, mucilage, tannins, resins, bitter principles, minerals, and vitamins [2]. Black cumin seeds are used as a seasoning in Turkey which is also called "Çörekotu".

Black cumin seeds have a composition of $0.5-1.5 \%$ essential oil. The essential oil contains thymoquinone $(27.8 \%-57.0 \%)$, p-cymene $(7.1 \%-15.5 \%)$, carvacrol $(5.8 \%-11.6 \%)$, trans-anethole $(0.25 \%-2.3 \%)$, 4-terpineol $(2.0 \%-6.6 \%)$, and longifolene $(1.0 \%-8.0 \%)$ as major components [2].

NS fixed oil has reported health benefits against headache, inflammation, fever, eczema, bronchitis, hypertension, asthma, diabetes and more [3, 4]. It could be obtained via hot solvent extraction, cold pressed, super critic $\mathrm{CO}_{2}$ extraction and micro wave assisted extraction technics [5]. NS oil is brownish yellow in colour containing thymoquinone (TQ), carvacrol, $\gamma$-terpinene, carvone, limonene, $o$-cymene as volatile compounds and high amount of unsaturated fatty acids such as linolenic and linoleic acids, oleic acid, arachidonic acid and eicosadienoic acid $[5,6]$.

Thymoquinone (2-isopropyl-5-methylbenzo-1,4-quinone); the lipid soluble monoterpene, is the most biologically active compound in NS seeds, essential and fixed oils. Chemical structure of TQ is shown in Figure 1. It has been extensively studied for its therapeutic properties [4, 7]. NS oil is getting more and more popular due to its high demand and so adulteration with less expensive vegetable oils is a big concern for quality assessment. Therefore TQ is also the analytical marker of commercially available NS oils. While fatty acid profile could be quantitated as methyl esters with gas chromatography, there are some methods developed for identification and quantification of TQ levels including: gas chromatography mass spectroscopy (GC-MS), high performance thin layer chromatography (HPTLC), high performance liquid chromatography (HPLC), stable isotope dilution gas chromatography mass spectroscopy (SID-GC-MS) technique, liquid 
chromatography coupled with electron spray ionization and tandem time of flight mass spectrometer (LCESI-TOF) [8-15]. Most of these methods need expensive instruments, long sample preparation and analysis times.<smiles>CC1=CC(=O)C(C(C)C)=CC1=O</smiles>

Figure 1. Chemical structure of thymoquinone.

In this study, we developed a simple and efficient analysis method for the quality assessment of NS oil using gas chromatography with flame ionization detector (GC-FID). The method was developed between the correlation of TQ and diethyl phthalate (DEP) as internal standard. DEP is an inexpensive synthetic plasticiser compound commercially available with high purity.

\section{RESULTS AND DISCUSSION}

\subsection{Optimization of GC-FID method}

Some important parameters were optimized to achieve the best performance from this method. The major parameters were selecting the proper column, oven temperature, internal standard and the concentration range. The column plays a significant role in chromatographic separation [16]. Wax (Polyethylene glycol - PEG) columns are good for volatile compounds but they have limited temperature range up to $250{ }^{\circ} \mathrm{C}$. Temperature effects the separation and relative retention times [17]. Therefore various oven temperature rates including the gradient programmes were investigated. Using an internal standard is recommended while performing a GC-FID analysis. Diethyl phthalate (DEP) was selected as internal standard (IS). DEP is an inexpensive, easy to find, volatile synthetic plasticiser which NS oil does not contains naturally. To avoid pre-separation of TQ from NS oil with solid phase extraction cartridges, n-hexane was chosen as a solvent which has the ability to dissolve both TQ containing oil and the IS.

An Agilent Model 7890B gas chromatograph equipped with a flame ionization detector and G4513A series auto injector were used during the analysis. A 5977E MSD electron impact ionization mass detector was utilized to control peak purities while developing the method. Separation was performed on a HP-5MS column $(30 \mathrm{~m}, 0.25 \mathrm{~mm} \mathrm{ID}, 0.25 \mu \mathrm{m})$ whose temperature range varies between $-60{ }^{\circ} \mathrm{C}$ up to $350{ }^{\circ} \mathrm{C}$ which enables to elute free fatty acids residues from the column. Helium was chosen as carrier gas, high purity $\mathrm{H}_{2}$ and dry air were supplied via generators for FID. Operation parameters were given in Table 1.

Table 1. Operation conditions for TQ analysis in black cumin seed oil by GC-FID.

\begin{tabular}{ll} 
Column & HP-5MS $(30 \mathrm{~m}, 0.25 \mathrm{~mm}$ ID, $0.25 \mu \mathrm{m})$ \\
Injection & Split $(20: 1), 5 \mu \mathrm{L}$ \\
Injector Temperature & $250^{\circ} \mathrm{C}$ \\
Carrier Gas Flow & $2 \mathrm{~mL} / \mathrm{min}$ \\
Hydrogen Gas Flow & $30 \mathrm{~mL} / \mathrm{min}$ \\
Dry Air Flow & $400 \mathrm{~mL} / \mathrm{min}$ \\
FID Temperature & $220^{\circ} \mathrm{C}$ \\
Oven Temperature Program & $100^{\circ} \mathrm{C}$ isothermal for 2.5 minutes \\
& $20^{\circ} \mathrm{C} /$ min ramp to $250^{\circ} \mathrm{C}$ \\
& $5^{\circ} \mathrm{C} /$ min ramp to $300^{\circ} \mathrm{C}$ \\
& $300^{\circ} \mathrm{C}$ isothermal for 10 minutes \\
\hline
\end{tabular}

\subsection{Method Validation}

Method validation was performed according to International Conference on Harmonization (ICH) Q2(R1) Validation of Analytical Procedures: Text and Methodology guidelines [18]. 


\subsubsection{Specificity}

The ICH documents define specificity as the ability to assess unequivocally the analyte in the presence of components that may be expected to be present, such as impurities, degradation products, and matrix components. To assess the specificity; n-hexane, IS solution ( $0.5 \mathrm{mg} / \mathrm{mL}$ DEP in $\mathrm{n}$-hexane), TQ reference substance in n-hexane, and NS oil diluted with IS solution were injected to the system. Both TQ and DEP peaks were examined with electron impact ionization mass detector for peak purities in the sample solution. No interference were found for TQ and IS. Figure 2(A) represents the chromatogram of TQ reference substance stock solution dissolved in IS solution and Figure 2(B) demonstrates the sample chromatogram (NS oil in IS solution).

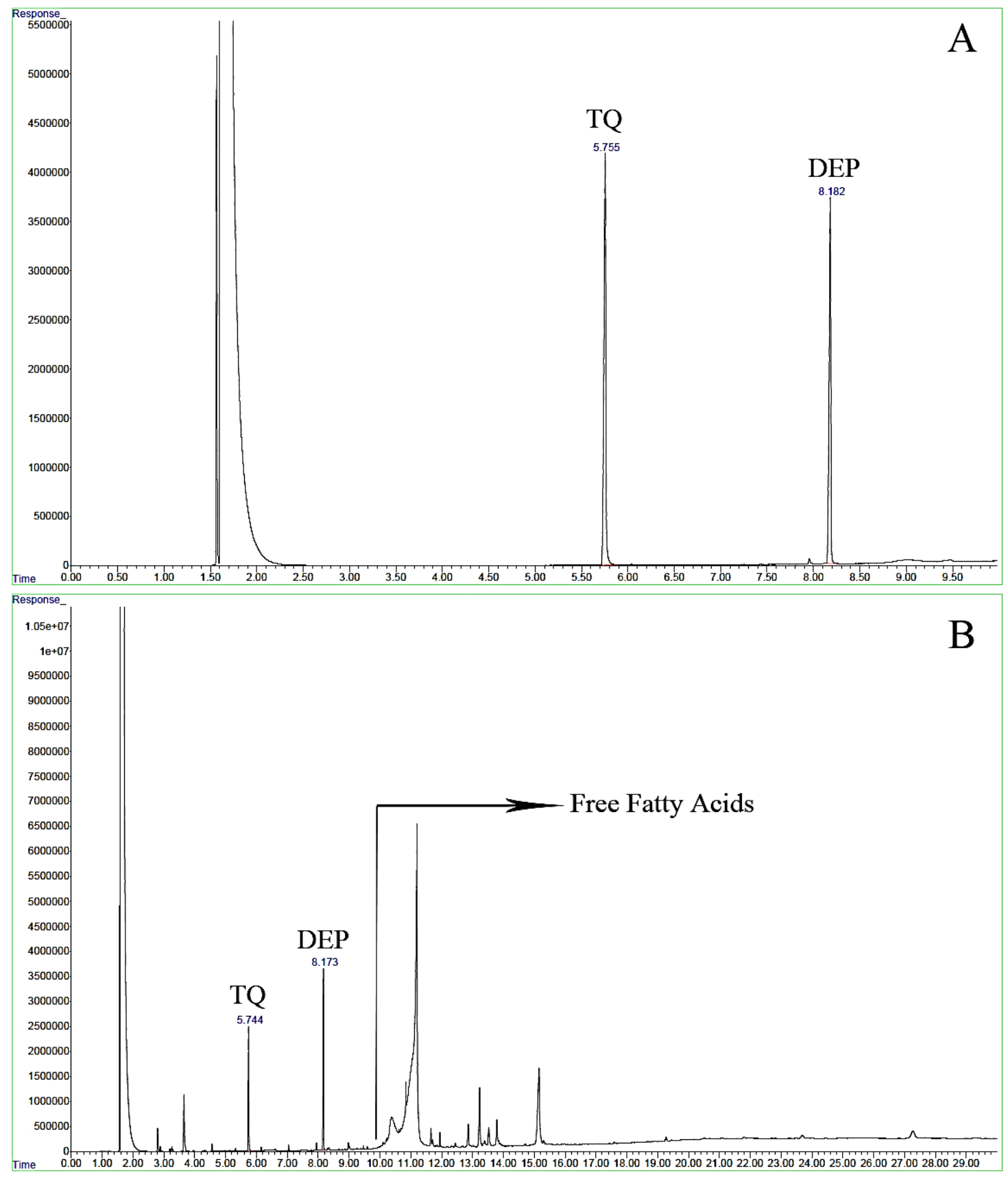

Figure 2. Chromatogram of (A) TQ reference solution dissolved in IS solution, (B) NS oil dissolved in IS solution. Free fatty acids eluting after DEP and peak purity of both TQ and DEP in sample solution were confirmed with mass detection. 


\subsubsection{Linearity}

The linearity of an analytical procedure is its ability to elicit test results that are directly, or by a welldefined mathematical transformation, proportional to the concentration of analyte in samples within a given range. The linearity of the method was achieved by injecting total seven samples with six different concentration of TQ stock solution in IS solution. Triplicate test results indicate that method is linear in studied concentration (see Table 2 and Figure 3). The equation of calibration curve graphic was used to generate the calculation formula in accuracy testing.

Table 2. The results illustrating linearity of the method. \% TQ/ \% DEP values are means of three replicate tests.

\begin{tabular}{llll}
\hline $\begin{array}{l}\text { TQ Concentration in } \\
\text { stock solution }(\mathrm{mg} / \mathrm{mL})\end{array}$ & $\begin{array}{l}\text { \% of TQ peak area in } \\
\text { chromatogram }\end{array}$ & $\begin{array}{l}\text { \% of DEP peak area } \\
\text { in Chromatogram }\end{array}$ & $\begin{array}{l}\text { \% Peak area of TQ/\% Peak area of } \\
\text { DEP }\end{array}$ \\
\hline 30 & 55.646 & 44.354 & 1.255 \\
15 & 38.133 & 61.867 & 0.616 \\
7.5 & 23.607 & 76.393 & 0.309 \\
3.75 & 14.550 & 85.450 & 0.170 \\
1.875 & 8.621 & 91.379 & 0.094 \\
0.9375 & 4.357 & 95.643 & 0.046 \\
0 & 0 & 100 & 0 \\
\hline
\end{tabular}

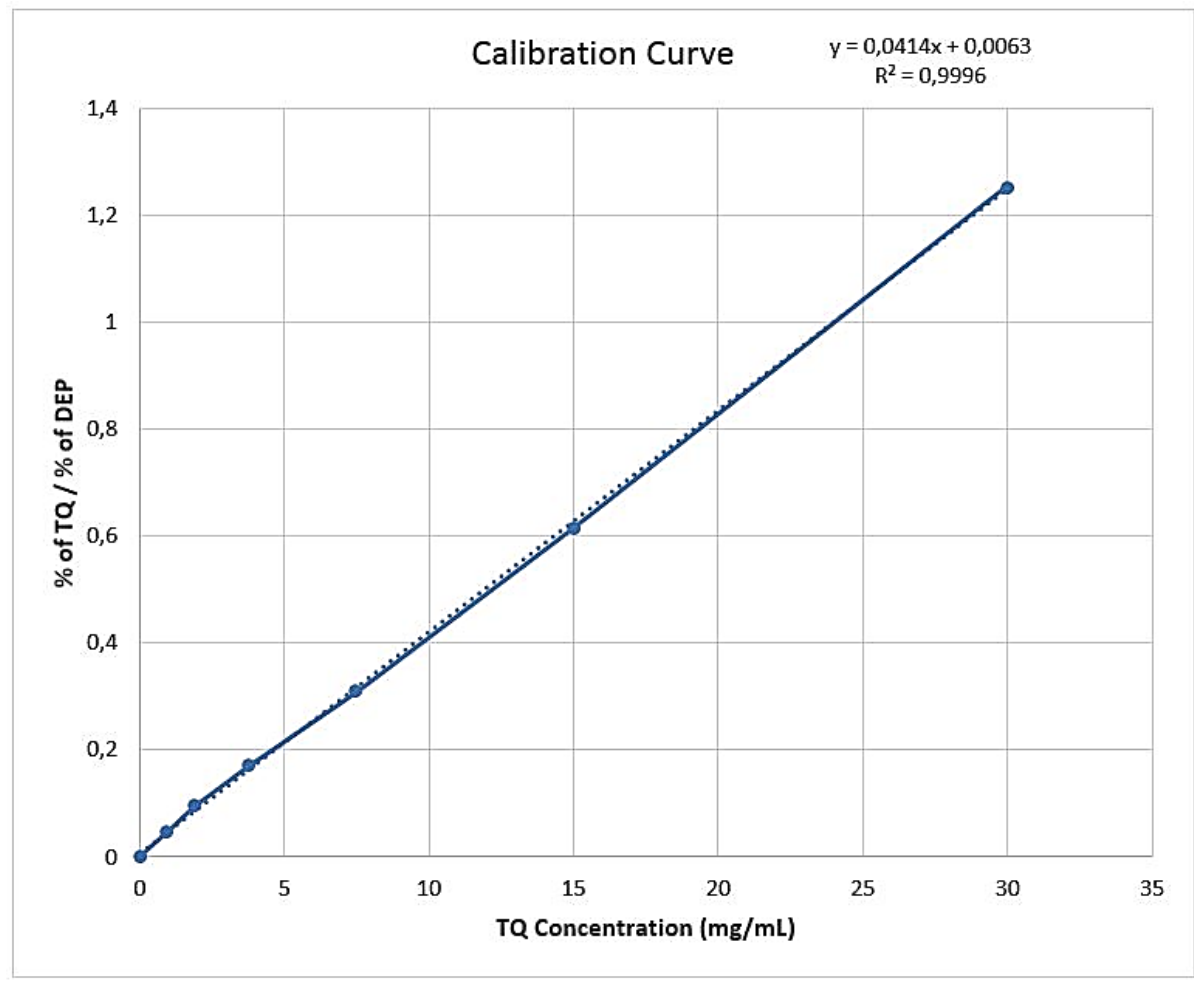

Figure 3. Calibration curve of TQ stock solution in IS solution. Graphic is plotted to the concentration of TQ stock solution used to prepare the sample against percent peak area ratios of both TQ and DEP in samples.

\subsubsection{Accuracy}

The accuracy of an analytical procedure is the closeness of test results obtained by that procedure to the true value. The accuracy of method was determined by means of recovery data from spike analysis. For this purpose TQ reference substance dissolved in corn oil in three different amounts. Three sample solutions were prepared from each corn oil sample spiked with TQ. Mean recovery was found \%100.505 as seen in Table 3. The equation generated before in linearity study was used to calculate TQ levels in samples as;

$$
\text { TQ in Corn Oil }(\mathrm{mg} / \mathrm{mL})=\frac{[(\% \text { Peak Area of TQ/\% Peak Area of DEP })-0.0063]}{0.0414}
$$


Table 3. The results demonstrating the recovery study.

\begin{tabular}{llllll}
\hline $\begin{array}{c}\text { TQ Spiked in } \\
\text { Corn Oil } \\
(\mathrm{mg} / \mathrm{mL})\end{array}$ & $\begin{array}{c}\text { \% of TQ Peak } \\
\text { Area in } \\
\text { Chromatogram }\end{array}$ & $\begin{array}{c}\text { \% of DEP Peak } \\
\text { Area in } \\
\text { Chromatogram }\end{array}$ & $\begin{array}{c}\text { \% Peak Area of } \\
\text { TQ/ Peak Area } \\
\text { of DEP }\end{array}$ & $\begin{array}{c}\text { Calculated } \\
\text { According to } \\
\text { Formula (mg/mL) }\end{array}$ & \% Recovered TQ \\
\hline 25 & 51.103 & 48.897 & 1.0451 & 25.092 & 100.369 \\
12.5 & 34.421 & 65.579 & 0.5249 & 12.526 & 100.208 \\
5 & 17.712 & 82.288 & 0.2152 & 5.047 & 100.939 \\
\hline Mean \pm SD & & & & $100.505 \pm 0,434$ \\
\hline
\end{tabular}

\subsubsection{Precision}

The precision of an analytical procedure is the degree of agreement among individual test results when the procedure is applied repeatedly to multiple samplings of a homogeneous sample. Precision of the method assessed in terms of repeatability, intermediate precision and reproducibility. Reproducibility refers to the use of the analytical procedure in different laboratories, as in a collaborative study. Intermediate precision (also known as ruggedness) expresses within-laboratory variation, as on different days, or with different analysts or equipment within the same laboratory. Repeatability refers to the use of the analytical procedure within a laboratory over a short period of time using the same analyst with the same equipment. Table 4 shows intermediate precision and repeatability data while Table 5 demonstrates the reproducibility of the method.

Table 4. The assessment of repeatability and intermediate precision.

\begin{tabular}{llll}
\hline $\begin{array}{c}\text { TQ Spiked in Corn Oil } \\
(\mathbf{m g} / \mathbf{m L})\end{array}$ & Analyst-1 & Analyst-2 \\
\hline 12.5 & 12.48 & 12.52 \\
12.5 & 12.50 & 12.47 \\
12.5 & 12.51 & 12.50 \\
12.5 & 12.49 & 12.51 \\
12.5 & 12.51 & 12.49 \\
12.5 & 12.47 & 12.53 \\
\hline \multicolumn{3}{c}{ Statistics } \\
\hline Mean \pm SD & $12,49 \pm 0,02$ & $12,50 \pm 0,03$ \\
\%RSD & 0,13 & 0,17 \\
\hline
\end{tabular}

Table 5. Data obtained from reproducibility study.

\begin{tabular}{|c|c|}
\hline TQ Spiked in Corn Oil (mg/mL) & Analyst-1 \\
\hline 12.5 & 12.47 \\
\hline 12.5 & 12.49 \\
\hline 12.5 & 12.45 \\
\hline 12.5 & 12.53 \\
\hline 12.5 & 12.52 \\
\hline 12.5 & 12.45 \\
\hline \multicolumn{2}{|c|}{ Statistics } \\
\hline Mean \pm SD & $12.49 \pm 0,04$ \\
\hline$\%$ RSD & 0.28 \\
\hline
\end{tabular}

\subsubsection{Limit of detection and limit quantification ( $L O D$ and $L O Q)$}

The detection limit is a characteristic of limit tests. It is the lowest amount of analyte in a sample that can be detected, but not necessarily quantitated, under the stated experimental conditions and the quantitation limit is a characteristic of quantitative assays for low levels of compounds in sample matrices. According to the ICH guidelines [17] LOD and LOQ calculated based on standard deviation of the response and the slope

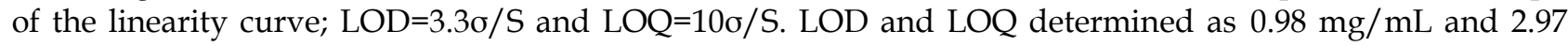
$\mathrm{mg} / \mathrm{mL}$ respectively.

Table 6 shows the TQ amounts of cold pressed and super critic $\mathrm{CO}_{2}$ extracted NS oils obtained from local producers analysed with the developed method. According to the previous studies, NS oil contains TQ between 3.48-8.73 $\mathrm{mg} / \mathrm{g}$ in cold pressed and 9.1-20.8 $\mathrm{mg} / \mathrm{g}$ in $\mathrm{CO}_{2}$ extracted $[10,19]$. 
Table 6. TQ levels of NS oil samples analysed with the developed method.

\begin{tabular}{lll}
\hline NS Oil Batch Number / Production Method & & THQ (mg/mL) \\
\hline AMZ-04-18 (Cold Pressed) & 7.18 & \\
AMZ-05-18 (Cold Pressed) & 6.29 \\
AMZ-07-18 (Cold Pressed) & 8.42 \\
OCY-03-18 (Cold Pressed) & 6.74 \\
UCY-05-18(Cold Pressed) & 7.51 \\
BCK-05-18 (Cold Pressed) & 9.63 \\
ETY-05-18 (Cold Pressed) & 5.49 \\
OSM-07-18 (Cold Pressed) & 6.31 \\
BCKS-05-18 (CO 2 Extracted) & 13.28 \\
HM-0718 (CO Extracted) & 19.36 \\
UZ0817 (CO $\mathrm{CO}_{2}$ Extracted) & 21.02 \\
BL0817 (CO $\mathrm{CO}_{2}$ Extracted) & 16.43
\end{tabular}

Figure 4 shows chromatograms obtained from two separate NSOs, which contain 0.56 and $12.75 \mathrm{mg} / \mathrm{mL}$ TQ respectively.

\section{CONCLUSION}

NS oil has a high amount of demand in the market because of its health benefits and adulteration becomes the major problem for quality assessment. Fatty acid profile could be analysed to make sure that the oils are unadulterated. On the other hand, the health benefits of NS oil are mostly connected to TQ. The amount of TQ defines the quality of NS oil and the developed method, which does not rely on expensive equipment and reference substances, could easily be applied to quantify TQ levels in the given concentration range in routine applications.

\section{MATERIALS AND METHODS}

\subsection{Instrumentation}

The method was developed using Agilent 7890B (California, USA) gas chromatography system equipped with flame ionization detector (FID). For peak purity studies system was coupled with Agilent 5977E electron ionization mass spectrometer. A G4513A auto injector was employed for sample injections. All system parameters for are shown in Table 1.

\subsection{Standard solutions and reagents}

TQ and DEP were obtained from Sigma-Aldrich (Missouri, USA), n-hexane was purchased from Merck (Darmstadt, Germany), corn oil and NS oils were obtained from local producers.

\subsection{Sample preparation and procedure}

TQ stock solutions were prepared with proper amount of TQ dissolved in n-hexane from $30 \mathrm{mg} / \mathrm{mL}$ to $0.9375 \mathrm{mg} / \mathrm{mL}$ by serial dilution. IS solution was prepared by use of $0.5 \mathrm{mg} / \mathrm{mL} \mathrm{DEP}$ in n-hexane. In order to prepare the calibration samples; $0.5 \mathrm{~mL}$ of TQ stock solutions were diluted to $25 \mathrm{~mL}$ with IS solution. The calibration curve was plotted to TQ concentration in stock solution against \% area of TQ/\% area of DEP. All calibration samples were analysed triplicate.

For recovery studies $25,12.5$ and $5 \mathrm{mg} / \mathrm{mL}$ TQ in corn oil samples were prepared. $0.5 \mathrm{~mL}$ of each samples were diluted to $25 \mathrm{~mL}$ with IS solution. Cold pressed and $\mathrm{CO}_{2}$ extracted NS oil samples were prepared by diluting $0.5 \mathrm{~mL}$ oil to $25 \mathrm{~mL}$ with IS solution. 


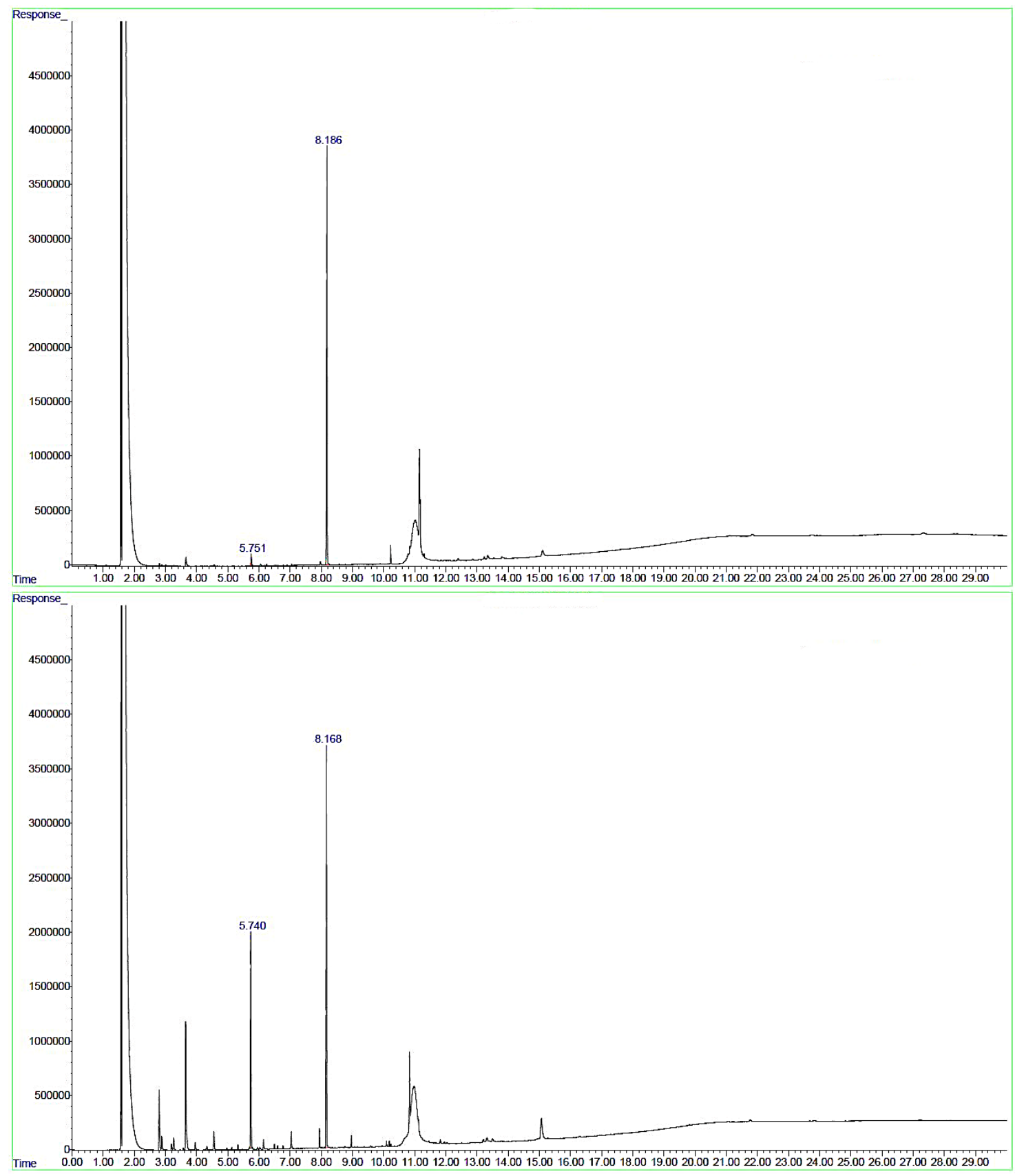

Figure 4. Chromatogram of $0.56 \mathrm{mg} / \mathrm{mL}$ THQ and $12.75 \mathrm{mg} / \mathrm{mL}$ THQ containing NSOs.

Author contributions: Concept - İ.D., M.K., Ü.K.; Design - İ.D., M.K., Ü.K.; Supervision - M.K.; Materials - İ.D., M.K., Ü.K.; Data Collection and/or Processing - İ.D., M.K. Ü.K.; Analysis and/or Interpretation - İ.D., M.K.; Literature Search - İ.D., M.K., Ü.K.; Writing - İ.D., M.K. Ü.K.; Critical Reviews - İ.D., M.K., Ü.K.

Conflict of interest statement: The authors declared no conflict of interest.

\section{REFERENCES}

[1] Cheikh-Rouhou S, Besbes S, Hentati B, Blecker C, Deroanne C, Atti H. Nigella sativa L.: Chemical composition and physicochemical characteristics of lipid fraction. Food Chem. 2007; 101(2): 673-681. [CrossRef]

[2] Macmudah S, Shiramizu Y, Motonubo G, Mitsuri S, Hirose T. Extraction of Nigella sativa L. using Supercritical CO2: A study of antioxidant activity of the extract. Sep Sci Technol. 2015; 40(6): 1267-1275 [CrossRef]

[3] Ramadan MF. Nutritional value, functional properties and nutraceutical applications of black cumin (Nigella sativa L.): An overview. Int J Food Sci Tech. 2007; 42: 1208-1218. [CrossRef] 
[4] Ali BH, Blunden G. Pharmacological and toxicological properties of Nigella sativa. Phytother Res. 2003; 17: 299-305. [CrossRef]

[5] Piras A, Rosa A, Marongiu B, Porcedda S, Falconieri D, Dessì MA, Ozcelik B, Koca U. Chemical composition and in vitro bioactivity of the volatile and fixed oils of Nigella sativa L. Extracted by supercritical carbon dioxide. Ind Crops Prod. 2013; 46: 317-323. [CrossRef]

[6] Al-Jassir MS. Chemical composition and microflora of black cumin (Nigella sativa L.) seeds growing in Saudi Arabia. Food Chem. 1992; 45 (4): 239-242. [CrossRef]

[7] Gali-Muhtasib H, Roessner A, Schneider-Stock R. Thymoquinone: A promising anti-cancer drug from natural sources. Int J Biochem Cell Biol. 2006; 38: 1249-1253. [CrossRef]

[8] Farag MA, El-Kersh DM, Rasheed DM, Heiss AG. Volatiles distribution in Nigella species (black cumin seeds) and in response to roasting as analyzed via solid-phase microextraction (SPME) coupled to chemometrics. Ind Crop Prod. 2017; 108: 564-571. [CrossRef]

[9] Velho-Pereira RM, Barhate CR, Kulkarni SR, Jagtap AG. Validated high-performance thin-layer chromatographic method for the quantification of thymoquinone in Nigella Sativa extracts and formulations. Phytochem Anal. 2011; 22: 367-373. [CrossRef]

[10] Lutterodt H, Luther M, Slavin M, Yin JJ, Parry J, Gao JM, Yu L. Fatty acid profile, thymoquinone content, oxidative stability, and antioxidant properties of cold-pressed black cumin seed oils. LWT - Food Sci Technol. 2010; 43: 14091413. [CrossRef]

[11] Harzallah JH, Kouidhi B, Flamini G, Bakhrouf A, Mahjoub T. Chemical composition, antimicrobial potential against cariogenic bacteria and cytotoxic activity of Tunisian Nigella sativa essential oil and thymoquinone. Food Chem. 2011; 129: 1469-1474. [CrossRef]

[12] Kiralan M. Volatile compounds of black cumin seeds (Nigella sativa L.) from microwave-heating and conventional roasting. J Food Sci. 2012; 77: 481-484. [CrossRef]

[13] Viuda-Martos M, Mohamady MA, Fernández-López J, Abd ElRazik KA, Omer EA, Pérez-Alvarez JA, Sendra E. In vitro antioxidant and antibacterial activities of essentials oils obtained from Egyptian aromatic plants. Food Control. 2011; 22: 1715-1722. [CrossRef]

[14] Johnson-Ajinwo OR, Li WW. Stable isotope dilution gas chromatography-mass spectrometry for quantification of thymoquinone in black cumin seed oil. J Agric Food Chem. 2014; 62: 5466-5471. [CrossRef]

[15] Farag MA, Gad HA, Heiss AG, Wessjohann LA. Metabolomics driven analysis of six Nigella species seeds via UPLCqTOF-MS and GC-MS coupled to chemometrics. Food Chem. 2014; 151: 333-342. [CrossRef]

[16] Jennings W. Gas Chromatography with Glass Capillary Columns. Academic Press. New York. 1980; 11: 173-182. [CrossRef]

[17] Taylor T. GC Temperature Programming - 10 Things You Absolutely Need to Know. LCGC North America. 2015; 33(6): 438.

[18] International Conference on Harmonization (ICH), ICH (Q2 (R1); Validation of Analytical Procedures: Text and methodology. International Conference on Harmonization, Geneva, Switzerland, 2005.

[19] Salea R, Widjojokusumo E, Hartanti AW, Veriansyah B, Tjandrawinata RR. Supercritical fluid carbon dioxide extraction of Nigella sativa (black cumin) seeds using taguchi method and full factorial design. Biochem Compd. 2013; 1: 1. [CrossRef] 